NBER WORKING PAPER SERIES

\title{
THE EFFECTS OF CONSUMER-DIRECTED HEALTH PLANS ON HEALTH CARE SPENDING
}

\author{
Anthony T. Lo Sasso \\ Lorens A. Helmchen \\ Robert Kaestner \\ Working Paper 15106 \\ http://www.nber.org/papers/w15106
}

\author{
NATIONAL BUREAU OF ECONOMIC RESEARCH \\ 1050 Massachusetts Avenue \\ Cambridge, MA 02138 \\ June 2009
}

We gratefully acknowledge numerous helpful suggestions from Tom Buchmueller, Roger Feldman, Will Manning, Steve Parente, and seminar participants at the American Economic Association annual meeting, the AcademyHealth annual research meeting, Rochester University, the Southeastern Health Economics Study Group, Tulane University, University of Illinois at Chicago, University of Minnesota, and the National Economists Club in Washington DC. The views expressed herein are those of the author(s) and do not necessarily reflect the views of the National Bureau of Economic Research.

NBER working papers are circulated for discussion and comment purposes. They have not been peerreviewed or been subject to the review by the NBER Board of Directors that accompanies official NBER publications.

(C) 2009 by Anthony T. Lo Sasso, Lorens A. Helmchen, and Robert Kaestner. All rights reserved. Short sections of text, not to exceed two paragraphs, may be quoted without explicit permission provided that full credit, including $\odot$ notice, is given to the source. 
The Effects of Consumer-Directed Health Plans on Health Care Spending Anthony T. Lo Sasso, Lorens A. Helmchen, and Robert Kaestner

NBER Working Paper No. 15106

June 2009

JEL No. I11,I18

\begin{abstract}
$\underline{\text { ABSTRACT }}$
We use unique data from an insurer that exclusively offers high-deductible, "consumer-directed" health plans to identify the effect of plan features, notably the spending account, on health care spending. Our results show that the marginal dollar in the spending account is entirely spent on outpatient and pharmacy services. In contrast, inpatient and out-of-pocket spending were not responsive to the amount in the spending account. Our results represent the first plausibly causal estimates of the components of consumer-driven health plans on health spending. The magnitudes of the effects suggest important moral hazard consequences to higher spending account levels.
\end{abstract}

Anthony T. Lo Sasso

Health Policy and Administration Division

School of Public Health

University of Illinois at Chicago

$1603 \mathrm{~W}$. Taylor

Chicago, IL 60612

losasso@uic.edu

Lorens A. Helmchen

University of Illinois at Chicago

School of Public Health

Room 753

1603 West Taylor Street

Chicago, IL 60612-4394

helmchen@uic.edu

\author{
Robert Kaestner \\ Institute of Government and Public Affairs \\ University of Illinois \\ 815 West Van Buren Street, Suite 525 \\ Chicago, IL 60607 \\ and NBER \\ kaestner@uic.edu
}




\section{Introduction}

Consumer-directed health plans (CDHPs) that feature relatively high deductibles and a tax advantaged account to pay for services received while deductible applies, have been growing over the past few years because many employers and insurers view them as a way to control health care costs. A recent survey indicated that 13\% of employers offered CDHPs in 2008, up from 7\% in 2006, and 8\% of workers were enrolled in such plans in 2008, up from 4\% in 2006 (Claxton et al. 2008). Approximately 26\% of employers who did not offer a CDHP said they were somewhat or very likely to offer such a plan in the next year. In addition, recent anecdotal reports suggest that the economic downturn is causing more families to turn to high deductible CDHPs as a means of cutting their premium expenditures (Alderman 2009).

CDHPs are controversial, however, presumably due to the greater cost sharing associated with them. Greater cost sharing exposes the consumer to greater financial liability and reduces consumer welfare, although it reduces moral hazard effects of insurance. Given the greater financial liability associated with a high deductible, the role of the tax advantaged account is critical in terms of evaluating the welfare implications of switching from more traditional insurance plans to a CDHP. The tax advantaged account has the potential to buffer consumers from the increased financial liability, but it can undo the incentive to reduce unnecessary care (i.e., moral hazard). Surprisingly, despite the large and growing interest in CDHP, relatively little is known about the effects of these plans, particularly the spending account, on health care use and spending, and health outcomes.

Specifically, how individuals respond to the cost sharing features of CDHPs has not been widely studied and prior studies of CDHPs have several limitations. Past research is commonly based on case studies of a handful of employers or small surveys of employer and employee 
attitudes and experiences with regard to CDHP (see Lo Sasso et al. 2004, Buntin et al. 2006; Feldman, Parente, and Christianson 2007; Wharam et al. 2007; Parente, Feldman, and Chen 2008). External validity is a distinct challenge when examining the experiences of just a few firms. A greater challenge facing prior studies is that they almost uniformly study CDHP as an add-on option to an employer's health plan offerings leading to difficult, if not intractable, selection bias. There is reason to suspect that individuals who choose to enroll in a relatively new health insurance product design over familiar alternatives such as a health maintenance organization (HMO) or preferred provider organization (PPO) are likely to differ on unobservable factors related to their anticipated health care utilization leading to biased inference.

We attempt to remedy the shortcomings of the existing literature by employing unique data from an insurance company that offers CDHPs in the small group market. The setting allows us exploit the considerable variation in policy characteristics across and within hundreds of small employers over time. Moreover, the context is one of full replacement with no competing plan options. Therefore, employees have no choice of plan and there is no selection at the employee level. The focus on the small group market makes this study particularly timely and relevant from a public policy perspective, as small employers represent one of the most dynamic sectors of the economy with respect to job growth and innovation. However, small employers have been noteworthy for their declining rate of offering health insurance in recent years. Some commentators hold out the hope that CDHPs, by offering a potentially lower cost insurance product, may allow more small employers to retain coverage for employees or restore coverage previously eliminated. 


\section{A Brief History of Consumer-Driven Health Plans}

In the late 1990s, after the managed care backlash had slowed the growth of HMOs and other supply-side mechanisms to restrain health care expenditures, discussion turned towards "defined contribution" health care benefits, borrowing the term from the revolution that happened in employer-sponsored pension benefits. The notion originally discussed was employers simply providing employees with a cash payment (or voucher) with which to purchase health insurance on their own. While the notion of employers "cashing out" of the provision of offering health insurance benefits to employees never materialized, early work by Gabel, Lo Sasso, and Rice (2002) summarized the essential character of the consumer-directed health care movement and its contrasting relationship with managed care:

At its heart, the consumer-driven health care movement seeks to combine incentives with information to enable consumers to make informed choices about non-life threatening health care. Managed care succeeded in restraining costs because a third-party (or in some cases, an at-risk physician) was placed in the role of saying "no" to patients. Managed care's effectiveness in constraining costs was also the source of its unpopularity. By contrast, consumer-driven health care is an effort to put patients in a position to say "no" to themselves. This can only happen if consumers are not only aware of the true cost, but have a personal stake in the cost, and have sufficient information and confidence to make treatment decisions. (Gabel et al. 2002, p. W396)

At that time, the early industry pioneers of CDHP (e.g., Definity Health, Lumenos, and Destiny Health) were offering products that allowed employers to establish notional (or actual cash) accounts out of which first-dollar coverage of health care spending was provided. Under most plans, unused account dollars were allowed to roll over into the following year. While the reasoning behind the rollover feature was clear- to avoid a rush to spend dollars late in the policy year - the legal status of allowing employees to roll over unused dollars had not been formally established until the IRS issued an administrative ruling in the summer of 2002 creating the Health Reimbursement Arrangement (HRA) as a legal entity (US Treasury, 2002). 
The key features of HRAs are the employer's contribution of notional pre-tax dollars to an account that can be observed and "managed" by the enrollee. Individuals are not able to contribute to these accounts and, as the accounts are notional, interest cannot be earned, nor can the accounts be paid out should the employee leave the company with positive balance in the account, a fact that limits the portability of HRAs. The HRA ruling, in addition to allowing rollover of unused account dollars, preserved a great deal of flexibility in the design of health insurance products. There are no predefined limits on account contributions, deductible levels, or any other common plan characteristic.

The 2003 Medicare Modernization Act (MMA) brought Health Savings Accounts (HSAs) into existence. HSAs are similar to HRAs in many respects, but have a few notable differences. First, contributions to the account are real, not notional, and hence may earn interest and are portable. Minimum deductibles associated with the accounts are limited to $\$ 1050$ for single enrollees and $\$ 2100$ for families (in 2006), though they may be higher. The total annual tax-preferred contributions cannot exceed the lesser of the deductible or $\$ 2700$ for singles or $\$ 5450$ for families.

\section{Consumer Response to CDHPs}

The basic structure of the problem that is faced by enrollees in a CDHP can be represented graphically as in panel A of Figure 1. The figure shows a stylized representation of the trade-off between consumption of health care versus all other goods and services in the context of a CDHP. We assume consumers receive money in a spending account that is earmarked exclusively for the purchase of health care, which in the simple model is not assumed to decrease income. The kinked budget line (ABC) represents the amount of consumption 
possible given available income and out-of-pocket prices for goods (including health care). The kink points are generated as a result of discontinuities in out-of-pocket prices for health care that result from the CDHP benefit design. Under this simple setting, health care purchased with account dollars, region 1 in the figure, is essentially free; the presence of first-dollar coverage via the account may result in an increase in health care consumed relative to traditional plan designs. However, once the account is exhausted consumers face the full price of health care services as indicated with the steeply sloped budget line in region 2 of the figure, often referred to a the "doughnut hole". When the deductible is reached another discontinuity in out-of-pocket prices faced by enrollees occurs, indicated at point C. At this point the policy reverts to a traditional "major medical" policy in which cost-sharing between the insurance company and the enrollee might be 90-10 coinsurance (up to an out-of-pocket maximum). In the static model some consumers will choose point B, which is displayed in Panel A with the indifference curve; other consumers with a greater willingness to pay for health care will choose to locate along other parts of the budget line, for example, in region 3.

Panel B displays an expansion of the spending account (region 1). The effect of the account expansion is to simultaneously shrink the "doughnut hole” (region 2) while shifting up the budget segment in region 3 . The additional spending account dollars clearly make the consumer better off as indicated by the outward shift of the budget line, which represents an expansion of the consumer's opportunity set. Most consumers, such as the one displayed in the figure, will likely spend the additional account dollars on health care as indicated by the move from point B to point B'; other consumers who were in region 3, for example, will also clearly spend more on health care as represented by the upward shift in the budget segment in region 3 
that occurs because the fewer dollars needed to spent in the doughnut hole as a result of the larger account represent an income effect in region 3.

Enrollees' utilization decisions will be affected by additional considerations beyond those indicated by the simple model above. First, enrollees in general are uncertain about their health care needs in the future. For example, consider an employee who expects to be in region 3 in each year. If by chance his actual spending in the current year is in region 1, he will hoard the money to reduce expected out-of-pocket spending caused by exposure to the doughnut hole in the next year. Thus, while it is tempting to think that all enrollees will deplete their account balances on health care (move to point B or B') in each year, it is possible that enrollees will hold back some discretionary spending because of uncertainty about future health care needs (precautionary saving). The inter-temporal consideration can be illustrated by thinking of panel A in Figure 1 as Year 1 and panel B as Year 2: if consumers did not reach point B in Year 1, they would experience an increase in their accounts as indicated in panel B in Year 2. Hence the decision to spend account dollars is tempered by their potential value in reducing exposure to out-of-pocket costs in the next policy year. However, on average (in expectation), all consumers should use all of the money in their spending accounts.

The second complication is the potential role of learning over time about how to use a spending account efficiently and to make the correct allocation. Given the period of our study, it is likely that this is the first CDHP to which enrollees have been exposed, and a learning curve could be present. In particular, it is likely to take some time for consumers to realize the actual price of health care from which most enrollees in traditional plan designs have been shielded. As consumers gain more experience with pricing and learn to anticipate their own health care needs 
with greater accuracy, we might expect to see differential relationships between health plan characteristics, such as the size of the spending account, and health care utilization over time. ${ }^{1}$

The final aspect to consider is the role of selection in determining who chooses to enroll in a CDHP. Prior work has found evidence of favorable selection when individuals are presented with the option of CDHP alongside traditional plan designs, a fact that has clouded prior estimates of the effects of CDH plans on utilization (Fowles et al. 2004; Parente, Feldman, and Christianson 2004). A distinct advantage of our data and methodological approach is that we will be able to minimize the effect of selection with respect to health care utilization because we focus on full replacement settings. Employees have no choice of plans. So a major source of potential bias that has plagued previous studies is not relevant to our study. Selection may still occur, however, but if it does it is at the firm level; firms may choose the account size and deductible based on the health care needs of the employees. Below, we discuss how we address this problem.

Other aspects of the CDHPs have familiar effects on consumer behavior. A larger deductible increases the size of region 2 and shifts the budget line in region 3 downward, which will lead to a decrease in spending on health care for those likely to choose region 3 (i.e., sicker people). A lower (consumer) coinsurance rate will flatten the slope of the line in region 3 and result in greater spending for those in region 3. It is clear that the effects of changes in the deductible and coinsurance should be larger for those likely to locate in region 3 than those in region 1 . We investigate this hypothesis below using age of enrollee as a proxy for underlying health and expected expenditure.

\footnotetext{
${ }^{1}$ We estimated models that allowed us to look separately at the effect of the account balance in the first year of enrollment versus subsequent years. We were generally not able to reject that the first year coefficient differed from coefficient for subsequent years. We do not present these results, but results are available by request.
} 


\section{Data and Plan Design}

The data for our study come from a health insurance company that has been selling CDHPs (both HRAs and HSAs) for several years in the small group market. The insurer sells CDHPs exclusively on a total replacement basis and almost all firms offer just one plan. ${ }^{2}$ Hence the most obvious form of selection— that by employees across diverse plan options provided by the employer-is not a concern. ${ }^{3}$

The data are health care claims and enrollment information for employers offering a CDHP. We have information on all claims for inpatient, outpatient, and pharmaceutical health care services throughout the policy year. ${ }^{4}$ In addition, we also have information on health plan characteristics including spending account "deposits" at the beginning of the insured period, rollover account balances from the prior year, deductible amount, coinsurance rates for both in- and out-of-network care (the claims data contain an indicator for network status of the provider), outof-pocket maximum levels, and copayments for pharmaceuticals. Importantly, we also observe when employers alter characteristics of their insurance policy from one year to the next.

We limit the sample to firms with two or more years of information because, as we describe below, we focus on within-firm variation to identify the effect of CDHP features on health care spending and utilization. This within-firm focus allows us to control for unmeasured time-invariant firm-specific factors that may be correlated with plan features and employee

\footnotetext{
${ }^{2}$ A small number of employers offered more than one plan design to employees in the study period. Most commonly, employees could select a higher or lower deductible option, but this only occurred in $3 \%$ of employers. The presence of multiple plan options can introduce selection concerns as individuals might select plans based on anticipated health care needs. The results reported below did not change appreciably when the employers offering both CDHPs and non-CDHPs were excluded from the sample.

${ }^{3}$ More subtle forms of selection are possible. For example, individuals may decide to drop or not take up in the first place offered health insurance and instead take advantage of coverage provided by a spouse or parent. Such selection would change the composition of employees in the firm over time.

${ }^{4}$ One concern is that enrollees will have reduced incentives to file claims for care for which there is no reimbursement. However, for enrollees to take advantage of provider network discounts they must display their insurance cards and the provider is then responsible for submitting claims to the insurer. In addition, consumers have an incentive to have spending recorded by the insurer in order more readily to meet the deductible. As a result, it is unlikely that enrollees will fail to report health care activity while in the doughnut hole.
} 
health care use (i.e., firm selection). We also limit the sample to firms that had 5 or more enrollees. In large firms, it is plausible that features of CDHPs are exogenous, but this is less likely to be the case in very small firms. In these settings it is easy to imagine that a single individual's health care use might alter the contribution and benefits policy for all. Therefore, we drop these small firms.

Table 1 presents information on the employer groups in our sample by year. The average group size is roughly constant over time and in the mid-20s, with a maximum firm size of 809 . There are 2,380 company-years representing 959 unique firms meeting our criterion. ${ }^{5}$ Note that the insurer displays marked growth in the number of employer groups offering its products over time. Our data go through the third quarter of 2006 and so we do not observe complete year information for firms whose policies began late in 2005. Accordingly, we use only observations that included full policy years (e.g., began no later than 8/1/05) and this reduces the number of firms by approximately half in 2005 policy year. Nearly 63\% of the firms are right-censored in that they continue to offer health insurance provided by the insurer beyond the period at which our claims data end; the remaining 37\% discontinued offering the insurer's products. We have no information on why the firms discontinued their relationship with the insurer.

Table 2 displays descriptive statistics for individual enrollees by policy year. Again we observe the pronounced growth in the number of enrollees over time (2005 represents approximately half of the firms). The spending account averaged roughly $\$ 900$ over the period with a deductible of nearly $\$ 1900$. The spending account is measured as the balance at the beginning of the policy year. Thus, the spending account includes three components: the contribution made by the firm, the contribution made by the individual, and the amount of any

\footnotetext{
${ }^{5}$ In the full sample including the very small groups and the firms with only one year of data there are 4,463 company-years representing 2,234 unique firms.
} 
roll-over from prior years. ${ }^{6}$ The deductible, out-of-pocket maximum, and hospital/surgery deductible tended to rise a bit over time; coinsurance rates did not vary a great deal over time. The out-of-pocket (OOP) maximum was roughly $\$ 7500$ and the hospital/surgery deductible averaged \$664. Coinsurance on in-network services was roughly 90\%; coinsurance on out-ofnetwork services was about $66 \%$.

Another plan design feature is that the insurer exempts hospital inpatient stays and outpatient surgery spending from the spending account and doughnut hole, though any subsequent outpatient follow-up or prescription drugs associated with the inpatient stay or outpatient surgery are still subject to the spending account and doughnut hole. Such care would generally exhaust the spending account for most individuals. A separate hospital/surgery deductible is applied to such treatment. To reduce incentives to skimp on the treatment of chronic conditions, a standard feature of the insurance plans of this insurer exempts approved classes of chronic medicines from the spending account and doughnut hole, allowing such utilization to treated as a "post-deductible" expenditure. ${ }^{7}$ In addition, enrollees are responsible for out-of-pocket copayments based on a $\$ 10 / \$ 25 / \$ 45$ (generic/preferred brand/non-preferred brand) tiered pharmacy benefit. ${ }^{8}$ Pharmaceutical copayments cannot be paid from the spending account. The intent of the copayment regime despite the presence of the spending account and the doughnut hole is to continue to provide incentives for enrollees to select less costly pharmaceuticals once the deductible has been exceeded.

Table 3 presents summary statistics on health care spending in the sample. Not surprisingly, spending in all categories increased over time. Total health care spending averaged

\footnotetext{
${ }^{6}$ The data do not allow us to distinguish between employer and employee contributions to the account.

${ }^{7}$ In more recent years employers were allowed the option of not treating chronic medicines any different from other types of utilization. However, very few groups chose to offer policies without the chronic rider.

${ }^{8}$ The copayment schedule began as $\$ 10 / 20 / 45$ and was switched for all enrollees in 2003 to $\$ 10 / 25 / 45$. In more recent years, employers had the option of instituting a $\$ 15 / 35 / 60$ copayment regime.
} 
nearly \$4600 over the period, with about \$2700 in outpatient and pharmaceutical spending and \$1800 in inpatient and outpatient surgery spending (with significantly greater variation); of the total $\$ 840$ was spent out of pocket by enrollees.

There are two limitations of the data that merit comment. First, we have no contemporaneous comparison group enrolled in a traditional health plan design. Second, we have no pre-CDHP data on utilization of or spending for care for the firms in the data. Small groups typically do not keep the detailed claims data for their employees, and more likely they would never have occasion to observe detailed claims collected by their insurer. When an employer does not renew its contract with the insurer we have no information on why (e.g. the company has chosen to eliminate health insurance benefits, opted for another carrier, or gone out of business). Likewise, we have no information on the reason an individual employee disenrolls from the plan. In light of the above limitations, our empirical methods (discussed in the next section) will take advantage of the variation in plan design within firms over time.

\section{Research Design}

Our objective is to estimate how employee spending on health care changes with the features of CDHPs. Ideally, we would estimate a model such as:

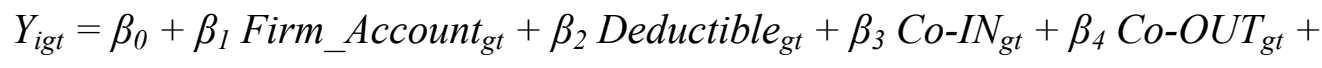

$$
\begin{aligned}
& \beta_{5} H S-D e d u c t_{g t}+\beta_{6} \text { OOP Max } \text { M }_{g t}+\gamma X_{i g t}+\eta_{g}+\varepsilon_{i g t},
\end{aligned}
$$

where $Y$ is total annual spending for person/family $i$ in company $g$ in year $t$, Firm_Account is the amount of dollars the firm contributes to the employee’s spending account at the beginning of the year, Deductible represents the deductible level after which enrollees are only responsible for coinsurance (Co-IN for in-network care and Co-OUT is the out-of-network care). HS-Deduct is 
the separate hospital inpatient/outpatient surgery deductible, OOP Max is the out-of-pocket maximum for patient coinsurance-related expenditures, $X$ represents personal characteristics (age, gender, number of dependents, year of tenure in the plan) as well as calendar year dummies, $\eta$ is a firm fixed effect, and $\varepsilon$ is an idiosyncratic error term.

Unfortunately, we do not observe Firm_Account. We observe only the amount in the employee’s spending account at the beginning of the year and this can include voluntary contributions. Therefore, we estimate:

$$
\begin{aligned}
& Y_{\text {igt }}=\beta_{0}+\beta_{1} \text { Total_Account }_{i g t}+\beta_{2} \text { Deductible }_{g t}+\beta_{3} \text { Co-IN } N_{g t}+\beta_{4} \text { Co-OUT } T_{g t}+ \\
& \beta_{5} H S-\text { Deduct }_{g t}+\beta_{6} \text { OOP Max } \text { Mt }+\gamma X_{i g t}+\eta_{g}+\varepsilon_{i g t}
\end{aligned}
$$

where Total_Account is measured at the employee level and includes the amount contributed by both the employer and the employee. Enrollee choice over contributions to spending accounts poses a challenge to estimating the causal relationship between the spending account level and health care spending. If individuals anticipate greater health care needs and consequently increase the funding of their account balance (adverse selection), we will observe an upward bias in uninstrumented regressions. Conversely, if more risk averse individuals (who may also have better health status) fund their accounts to a greater extent (advantageous selection), we will observe a downward bias in uninstrumented regressions. In addition, to the extent healthier people fail to spend their account balance they will experience greater roll-over of account balances from one year to the next relative to less healthy individuals; such a relationship would also lead to a downward bias. ${ }^{9}$

In order to mitigate the potential bias from endogenous account balances, we use an instrumental variables (IV) strategy. We instrument for Total_Account using the minimum

\footnotetext{
${ }^{9}$ Also, in principle we might expect individuals to place a greater value on dollars in an HSA given the portability they afford relative to HRAs. In our data only roughly $2 \%$ of firms offered HSAs so we are unable to test this hypothesis.
} 
account balance, which is measured at the beginning of the policy year, among employees in firm g and year t. Further, the minimum account balance is specific to employees in each coverage option: single, employee plus one dependent, employee plus two or more dependents. Hence to the extent that at least one employee in each coverage option-firm-year cell chooses not to contribute to their account (the calculation excludes rollover dollars), our approach will represent a reasonable estimate of the firm's contribution to the account. The mean minimum spending account calculated in this manner is roughly half of the average spending account. In addition, there could be a qualitative difference in the effect for cases in which the employer contributes nothing to the account versus contributing something to the account, we allow for a discontinuity for zero dollar contributions. The first stage of the instrumental variables procedure is:

$$
\begin{aligned}
& \text { Total_Account } \text { igt }_{1}=\alpha_{0}+a_{1} \text { Min_Account }_{g t}+a_{2} \text { Min_Zero }_{g t}+a_{3} \text { Deductible }_{g t}+a_{3} \text { Co-IN } \text { It }_{\text {B }}+ \\
& a_{4} \mathrm{Co}-\mathrm{OUT} T_{g t}+a_{5} H S-\text { Deduct } t_{g t}+a_{6} \mathrm{OOP} \mathrm{Max}_{g t}+a_{7} Z_{g t}+a_{8} X_{i g t}+r_{g}+u_{i g t},
\end{aligned}
$$

where the model also includes a full set of interaction terms between Min_Account, Min_Zero and the other plan characteristics (summarized by the vector $Z$ in equation 3). The interaction terms use the information provided by other plan features to help predict the (exogenous) spending account, as other features of the CDHPs are likely to be correlated with the size of the employer contribution to the spending account. Equation (3) is used to obtain a predicted value of Total_Account that will be used in equation (2).

The efficacy of the instrumental variables procedure depends on two conditions: how well Min_Account (and interactions) predicts Total_Account and whether Min_Account is legitimately excludable from equation (2). The first condition is well satisfied in our data. The minimum account balance in the firm is a strong predictor of the individual spending account 
balance conditional on other covariates in equation (3) even when firm fixed effects are included. This would be expected because the firm contributes a common component (perhaps zero) to all employees and this common component will generate a non-zero covariance between the minimum account balance in the firm and individual spending account balances.

The validity of the second condition cannot be assessed in an empirically definitive way. Excluding Min_Account from equation (2) assumes that the firm does not change the amount it contributes to the spending account in response to changes in employee spending or health care use (beyond that measured by general inflation in health care that is absorbed by year fixed effects). This assumption more likely holds in larger groups, and for this reason we exclude the very small groups. In very small employer settings it is difficult to argue that benefit levels are determined exogenously to the health care needs of the employees. In settings with only a few employees it is easy to imagine that a single individual's need might alter the contribution and benefits policy for all. A second assumption underlying the exclusion restriction is that Min_Account is unrelated to changes in individual choices to contribute to the spending that are driven by changes in health. We argue that this is likely. All that is necessary is that we observe an employee in the same part (minimum) of the spending account distribution in each year. Consider a firm that has not changed its contribution to the spending account. In this case, and ignoring learning, we should observe the same minimum spending account for that firm. It does not have to be the same employee, only an employee with the same minimum.

\section{Results}

Table 4 presents estimates of the effect of insurance plan features on four types of health care spending: total spending, outpatient/pharmacy spending, out-of-pocket spending, and 
spending on inpatient/outpatient surgery. For each type of spending, two sets of estimates are presented: OLS and IV. ${ }^{10}$ As discussed, we expect increases in the spending account to have a positive effect on spending. Higher deductibles are expected to decrease spending, as are higher (consumer) coinsurance rates.

We begin with estimates pertaining to total spending. OLS estimates indicate that an additional dollar in the spending account is associated with a significant increase of 1.2 dollars of total spending. The corresponding IV estimate is 0.92 and not statistically significant. Both estimates, however, suggests that, in accordance with Figure 1, each additional dollar in the spending account leads to an additional dollar spent on health care. The elasticity associated with these estimates ranges from 0.18 (IV) to 0.24 (OLS). Qualitatively, the OLS and IV results do not differ significantly, which is a finding that is also observed for other types of spending when the precision of the IV estimates is better. Assuming that our exclusion restrictions are valid, this finding suggests that there is not much selection. The selection we are concerned with is time-varying firm level selection (we condition on firm fixed effects) and/or time-varying individual level selection (plans are full replacement and employees have no choice). As we noted earlier, the problem of time-varying firm level selection is mitigated by the exclusion of small firms. Thus, the absence of significant evidence of selection implies that there is not much individual selection—individuals do not seem to be altering their contribution to their accounts in response to changes in their health (spending).

Regarding other plan characteristics the deductible has a predictable negative effect on total spending: each additional dollar increase in the deductible is associated with a 55 cent decrease in total spending, which corresponds to an elasticity of 0.23 . In-network coinsurance

\footnotetext{
${ }^{10}$ In addition, we estimated two-part models that allow us to distinguish between effects on the extensive margin and the intensive margin. We found generally symmetric results for plan characteristics across both margins [results available by request].
} 
paid by the plan has a positive effect on total spending: a percentage point increase in the coinsurance rate leads to an 82 dollar increase in total spending, which corresponds to an elasticity of 0.17 . In addition, the hospital inpatient/outpatient surgery deductible is negatively associated with spending. Age, number of dependents, and female gender are all positive correlates of higher spending [not displayed].

The next columns in Table 4 display analogous regressions for outpatient and pharmaceutical spending. The results are similar to the results observed for total spending. We now see that each additional dollar in the spending account is associated with an additional dollar spent predominantly on outpatient care and pharmaceuticals; this is precisely what we would expect given that spending account dollars are only applicable to non-inpatient and nonoutpatient surgery care. The coefficients imply an elasticity of spending account dollars to outpatient/pharmacy spending of 0.28 to 0.43 . As with the total spending regressions, an increase in the deductible is associated with a decrease in outpatient/pharmacy spending (elasticity of 0.17), and an increase in in-network coinsurance is associated with an increase in outpatient/pharmacy spending (elasticity of 0.13).

The next columns display regressions for out-of-pocket spending. The theoretical framework does not produce a clear prediction for out-of-pocket spending: while more generous plan features such as a larger spending account or lower deductible, all else constant, should be protective against out-of-pocket expenditures, the additional health care purchases induced by more generous plan features could be accompanied by increased out-of-pocket spending. For example, all prescription drugs have out-of-pocket copayments associated with them that cannot be paid from the spending account. We cannot reject that any plan features have effects on OOP spending that are significantly different from zero. Most of our IV coefficient estimates have 
fairly precise standard errors, though at least in the case of the spending account the standard error does not let us rule out relatively large effect sizes.

The final column of Table 4 displays regression results for hospital inpatient and outpatient surgery spending, which as previously noted is treated differently from other spending under the benefit design in that it is not subject to spending account and deductible considerations. However, there is a separate deductible for inpatient care. Despite this, given any complementarities between outpatient and inpatient care are complements, there could exist a positive relationship between the spending account/deductible and inpatient spending. Our findings are consistent with a complementary relationship in that the deductible that should apply only to outpatient care has a negative effect on inpatient care; likewise there is some evidence of a positive effect of spending account dollars on inpatient care, though the IV estimate is not precisely measured. The hospital/surgery deductible while negative is not statistically different from zero.

Theory suggests that aspects of the insurance plan such as the deductible and coinsurance have different effects depending on where enrollees are in the spending distribution. Specifically, the effects of the deductible and coinsurance rates should be greater for individuals more likely to be in region 3 of Figure 1 . To examine this, Table 5 displays results that stratify by age 50 or over and less than 50 years of age. ${ }^{11}$ In addition, because selection associated with account balances appeared to be minimal, and IV estimates somewhat imprecise, we only show OLS results in Table 5.

Estimates in Table 5 are for the most part consistent with theoretical predictions, although standard errors are too large to draw definitive conclusions. Changes in the deductible are associated with larger changes in spending for those over age 50, and presumably healthier and

\footnotetext{
${ }^{11}$ The stratification is not perfect as older workers may have younger dependents on their policy.
} 
likely to be in region 3 (Figure 1), than for those under age 50. Estimates with regard to coinsurance are mixed with respect to theoretical predictions, but these estimates are quite imprecise.

\section{Discussion}

The goal of our research was to identify the effect of features of consumer-directed health insurance policies—-notably the spending account level—on health care spending. How individuals respond to such cost sharing has not received a thorough treatment since the RAND Health Insurance Experiment (HIE) of the mid-1970s (Newhouse 1994), and the spending account component of the plan design did not exist at that time. Our results show that enrollees tend to treat the marginal dollar in the spending account as an apparent shift in "permanent income” in that the entire dollar is spent on health care. Outpatient and pharmacy spending was responsive to the size of the spending account, while inpatient spending was not—a relationship in accordance with the design of the benefit. Spending account dollars and other plan features had no statistically significant effect on out-of-pocket spending.

While the direction of our findings are not necessarily surprising, the magnitudes of the effects suggest important moral hazard consequences to higher spending account levels. An equal increase in the deductible and contribution to a spending account will increase total health care spending. Theoretically, this is because those who expect to spend relatively little (i.e., healthy) spend more than they would under such a change, and those who expect to spend a lot (i.e., sick) are unaffected by an equal change in the account and deductible. In fact, our estimates indicate that, on average, an increase in the deductible that is twice as large as an increase in the spending account would result in no change in total spending. Moreover, because the deductible 
has relatively little effect on healthy persons, this tradeoff between a higher deductibles and a higher spending account has a particularly large effect on spending; estimates indicate that the deductible would have to be raised by almost $\$ 4$ for every $\$ 1$ increase in the spending account to keep spending unchanged.

These are important findings because they confirm theory suggesting that moral hazard is least problematic for services that have an inelastic demand such as inpatient services. Holding constant the spending account, increases in the deductible are intended to decrease moral hazard among those with large expected expenditures because such an increase will have little effect on those with relatively small expected expenditures (see Figure 1). The upshot of this discussion is that trading a dollar of deductible for a dollar of spending account is a poor idea and will result in increased expenditures, particularly when the enrollee group is comprised of younger workers. It will also tend to make sicker persons worse off for little gain, as there will be relatively little reduction in care and thus little reduction in inefficient care (moral hazard).

Our results have important implications for benefit design and for firms considering offering CDH plans to their employees. Employers need to use caution in deciding on account contribution levels. Some amount of funding for the account may be necessary to induce "buyin” for a switch to high-deductible policy from employees, but this would need to be weighed against the moral hazard engendered by the contribution.

It is not clear the extent to which we can generalize from the small group market. For example, the small group health insurance market is much more subject to state regulations, some of which prevent insurers from even offering HRA/HSA products. However, there are no compelling reasons why workers at small companies would respond differently to health plan characteristics than workers at large companies. There may also be peculiarities about the 
employers who decided to offer a CDHP in the first place: why did they choose this product when they did? It is possible that the reasons could be related to the health spending outcomes of interest in this study. 


\section{References}

Alderman L., “Advice to the Jobless on Getting Health Coverage,” New York Times. February 28, 2009: B6.

Buntin, Melinda Beeuwkes, Cheryl Damberg, Amelia Haviland, Kanika Kapur, Nicole Lurie, Roland McDevitt, and M. Susan Marquis, "Consumer-Directed Health Care: Early Evidence About Effects On Cost And Quality,” Health Affairs 2006, 25(6): w516-w530.

Claxton, Gary, Jon Gabel, Bianca DiJulio, Jeremy Pickreign, Heidi Whitmore, Benjamin Finder, Marian Jarlenski, and Samantha Hawkins. "Health Benefits in 2008: Premium Moderately Higher, While Enrollment in Consumer-Directed Plans Rises in Small Firms,” Health Affairs September 24, 2008 http://content.healthaffairs.org/cgi/content/abstract/hlthaff.27.6.w492.

Feldman, Roger, Stephen T. Parente, and Jon B. Christianson. "Consumer-Directed Health Plans: New Evidence on Spending and Utilization,” Inquiry Spring 2007, 44: 26-40.

Fowles JB, E.A. Kind, B.L. Braun, J. Bertko, “Early Experience with Employee Choice of Consumer-Directed Health Plans and Satisfaction with Enrollment.” Health Services Research 2004, 39(4, Part 2): 1141-1158.

Gabel, Jon, Anthony T. Lo Sasso, and Thomas Rice, “Consumer-Choice Plans: Are They More Than Talk Now?” Health Affairs, November 20, 2002 http://content.healthaffairs.org/cgi/content/abstract/hlthaff.w2.395v1.

Lo Sasso Anthony T., Thomas Rice, Jon Gabel, Heidi Whitmore, "Tales from the New Frontier: Pioneers’ Experiences with Consumer-Driven Health Care.” Health Services Research 2004, 39(4, part 2):1071-1089.

Newhouse, J.P., and the Insurance Experiment Group. Free for All? Lessons from the RAND Health Insurance Experiment (Cambridge, Mass.: Harvard University Press, 1994).

Parente, Stephen T., Roger Feldman, Song Chen, "Effects of a Consumer Driven Health Plan on Pharmaceutical Spending and Utilization.” Health Services Research 2008, 43(5):15421556.

Parente, Stephen T., Roger Feldman, Jon B. Christianson. "Evaluation of the Effect of a Consumer-Driven Health Plan on Medical Care Expenditures and Utilization,” Health Services Research 2004, 39(4, Part 2): 1189-1210.

U.S. Department of Treasury, Internal Revenue Service Notice 2002-45; Rev. Rul. 2002-41.

Wharam, J.F., B. E. Landon, A. A. Galbraith, K. P. Kleinman, S. B. Soumerai, and D. RossDegnan, "Emergency Department Use and Subsequent Hospitalizations Among Members of a High-Deductible Health Plan,” JAMA 2007, 297(10): 1093 - 1102. 
Table 1: Descriptive statistics of enrollment by year

\begin{tabular}{|l|c|c|c|c|c|c|c|}
\hline $\begin{array}{c}\text { Policy Year } \\
\text { Beginning }\end{array}$ & 2000 & 2001 & 2002 & 2003 & 2004 & $2005^{2}$ & Total \\
\hline $\begin{array}{l}\text { Total enrollment } \\
\text { (standard deviation) }\end{array}$ & $\begin{array}{c}28.7 \\
(28.7)\end{array}$ & $\begin{array}{c}29.0 \\
(43.0)\end{array}$ & $\begin{array}{c}23.4 \\
(28.7)\end{array}$ & $\begin{array}{c}24.4 \\
(41.5)\end{array}$ & $\begin{array}{c}23.7 \\
(33.2)\end{array}$ & $\begin{array}{c}23.1 \\
(39.3)\end{array}$ & $\begin{array}{c}23.9 \\
(36.6)\end{array}$ \\
\hline Min $^{1}$ & 7 & 5 & 5 & 5 & 5 & 5 & 5 \\
\hline Max & 69 & 210 & 211 & 809 & 599 & 679 & 809 \\
\hline $\begin{array}{l}\text { N [Employers / } \\
\text { Groups] }\end{array}$ & 6 & 7 & 323 & 579 & 830 & 572 & 2380 \\
\hline N [Enrollees] & 172 & 2,032 & 7,551 & 14,131 & 19,706 & 13,217 & 56,809 \\
\hline
\end{tabular}

${ }^{1}$ Sample only includes firms with 5 or more enrollees.

${ }^{2}$ includes only employers whose policy years began no later than 8/1/2005. 
Table 2: Descriptive statistics of enrollee and plan characteristics over time

\begin{tabular}{|c|c|c|c|c|c|c|c|}
\hline $\begin{array}{c}\text { Policy Year } \\
\text { Beginning }\end{array}$ & 2000 & 2001 & 2002 & 2003 & 2004 & $2005^{2}$ & Total \\
\hline \multicolumn{8}{|l|}{ Plan Characteristics } \\
\hline Spending account & $\begin{array}{c}672 \\
(864)\end{array}$ & $\begin{array}{c}823 \\
(702)\end{array}$ & $\begin{array}{c}857 \\
(697)\end{array}$ & $\begin{array}{c}859 \\
(722)\end{array}$ & $\begin{array}{c}886 \\
(784)\end{array}$ & $\begin{array}{l}1006 \\
(891)\end{array}$ & $\begin{array}{c}901 \\
(785)\end{array}$ \\
\hline Deductible & $\begin{array}{c}3902 \\
(4048) \\
\end{array}$ & $\begin{array}{c}1733 \\
(1359) \\
\end{array}$ & $\begin{array}{l}1629 \\
(932) \\
\end{array}$ & $\begin{array}{c}1886 \\
(1313)\end{array}$ & $\begin{array}{c}1903 \\
(1186) \\
\end{array}$ & $\begin{array}{l}1938 \\
(978) \\
\end{array}$ & $\begin{array}{c}1870 \\
(1180)\end{array}$ \\
\hline OOP max & $\begin{array}{c}5000 \\
(0)\end{array}$ & $\begin{array}{c}5960 \\
(1970)\end{array}$ & $\begin{array}{c}6253 \\
(2554)\end{array}$ & $\begin{array}{c}7616 \\
(4415)\end{array}$ & $\begin{array}{c}7609 \\
(4212)\end{array}$ & $\begin{array}{c}7851 \\
(4488)\end{array}$ & $\begin{array}{l}7420 \\
(4127)\end{array}$ \\
\hline $\begin{array}{l}\text { In-network } \\
\text { coinsurance }\end{array}$ & $\begin{array}{r}86.2 \\
(5.2) \\
\end{array}$ & $\begin{array}{l}90.3 \\
(5.5) \\
\end{array}$ & $\begin{array}{l}89.6 \\
(5.8) \\
\end{array}$ & $\begin{array}{l}90.6 \\
(6.7) \\
\end{array}$ & $\begin{array}{l}90.5 \\
(6.7) \\
\end{array}$ & $\begin{array}{l}91.3 \\
(6.7) \\
\end{array}$ & $\begin{array}{l}90.6 \\
(6.6) \\
\end{array}$ \\
\hline $\begin{array}{l}\text { Out-of-network } \\
\text { coinsurance }\end{array}$ & $\begin{array}{r}66.2 \\
(5.2)\end{array}$ & $\begin{array}{l}70.3 \\
(5.5)\end{array}$ & $\begin{array}{l}69.0 \\
(6.3)\end{array}$ & $\begin{array}{l}65.6 \\
(8.9)\end{array}$ & $\begin{array}{l}65.9 \\
(8.6)\end{array}$ & $\begin{array}{l}66.1 \\
(9.1)\end{array}$ & $\begin{array}{l}66.5 \\
(8.6)\end{array}$ \\
\hline $\begin{array}{l}\text { Hospital/surgery } \\
\text { deductible }\end{array}$ & $\begin{array}{c}0 \\
(0)\end{array}$ & $\begin{array}{c}327 \\
(282)\end{array}$ & $\begin{array}{c}470 \\
(332) \\
\end{array}$ & $\begin{array}{c}787 \\
(1082)\end{array}$ & $\begin{array}{c}669 \\
(883) \\
\end{array}$ & $\begin{array}{c}696 \\
(1004)\end{array}$ & $\begin{array}{c}664 \\
(910) \\
\end{array}$ \\
\hline \multicolumn{8}{|c|}{ Enrollee Characteristics } \\
\hline Age & $\begin{array}{c}42.7 \\
(12.3)\end{array}$ & $\begin{array}{c}38.5 \\
(11.6)\end{array}$ & $\begin{array}{c}40.2 \\
(12.0)\end{array}$ & $\begin{array}{c}40.0 \\
(12.1)\end{array}$ & $\begin{array}{c}40.8 \\
(12.0)\end{array}$ & $\begin{array}{c}41.6 \\
(12.1)\end{array}$ & $\begin{array}{c}40.6 \\
(12.1)\end{array}$ \\
\hline Female & .53 & .36 & .38 & .37 & .39 & .40 & .39 \\
\hline Tenure in plan & $\begin{array}{c}1 \\
(0)\end{array}$ & $\begin{array}{c}1.06 \\
(0.24)\end{array}$ & $\begin{array}{c}1.22 \\
(0.45)\end{array}$ & $\begin{array}{c}1.46 \\
(0.63)\end{array}$ & $\begin{array}{c}1.73 \\
(0.85)\end{array}$ & $\begin{array}{c}2.29 \\
(0.86)\end{array}$ & $\begin{array}{c}1.70 \\
(0.83)\end{array}$ \\
\hline Single & 0.66 & 0.54 & 0.53 & 0.55 & 0.55 & 0.54 & 0.54 \\
\hline Employee +1 & 0.12 & 0.16 & 0.18 & 0.17 & 0.17 & 0.17 & 0.17 \\
\hline Employee +2 & 0.22 & 0.30 & 0.39 & 0.28 & 0.28 & 0.29 & 0.29 \\
\hline $\begin{array}{c}\text { Number of } \\
\text { dependents }\end{array}$ & $\begin{array}{c}.84 \\
(1.48)\end{array}$ & $\begin{array}{c}1.11 \\
(1.53)\end{array}$ & $\begin{array}{c}1.07 \\
(1.46)\end{array}$ & $\begin{array}{c}1.04 \\
(1.44)\end{array}$ & $\begin{array}{c}1.04 \\
(1.43)\end{array}$ & $\begin{array}{c}1.05 \\
(1.42)\end{array}$ & $\begin{array}{c}1.05 \\
(1.44)\end{array}$ \\
\hline $\mathbf{N}$ & 172 & 2,032 & 7,551 & 14,131 & 19,706 & 13,217 & 56,809 \\
\hline
\end{tabular}

Standard deviations presented in parentheses.

Notes: family coverage is treated as one insurance unit

${ }^{2}$ includes only employers whose policy years began no later than 8/1/2005.

OOP max is out-of-pocket maximum for patient coinsurance-related expenditures. 
Table 3: Descriptive statistics of health care spending

\begin{tabular}{|l|c|c|c|c|c|c|c|}
\hline \multicolumn{1}{|c|}{$\begin{array}{c}\text { Policy Year } \\
\text { Beginning }\end{array}$} & $\mathbf{2 0 0 0}$ & $\mathbf{2 0 0 1}$ & $\mathbf{2 0 0 2}$ & $\mathbf{2 0 0 3}$ & $\mathbf{2 0 0 4}$ & $\mathbf{2 0 0 5}$ & Total \\
\hline $\begin{array}{l}\text { Total health care } \\
\text { spending }\end{array}$ & $\begin{array}{c}2313 \\
(4957)\end{array}$ & $\begin{array}{c}4199 \\
(16823)\end{array}$ & $\begin{array}{c}4534 \\
(16473)\end{array}$ & $\begin{array}{c}4297 \\
(14283)\end{array}$ & $\begin{array}{c}4445 \\
(14919)\end{array}$ & $\begin{array}{c}5172 \\
(15210)\end{array}$ & $\begin{array}{c}4574 \\
(15105)\end{array}$ \\
\hline $\begin{array}{l}\text { Total OP/Rx } \\
\text { spending }\end{array}$ & $\begin{array}{c}1562 \\
(2875)\end{array}$ & $\begin{array}{c}2550 \\
(10144)\end{array}$ & $\begin{array}{c}2638 \\
(5234)\end{array}$ & $\begin{array}{c}2645 \\
(7132)\end{array}$ & $\begin{array}{c}2650 \\
(5122)\end{array}$ & $\begin{array}{c}3040 \\
(5418)\end{array}$ & $\begin{array}{c}2731 \\
(5997)\end{array}$ \\
\hline Total IP/OP surgery & 750 & 1650 & 1896 & 1652 & 1795 & 2132 & 1843 \\
spending & $(2869)$ & $(9115)$ & $(13598)$ & $(10247)$ & $(12172)$ & $(12382)$ & $(11865)$ \\
\hline Total out-of-pocket & 670 & 704 & 764 & 899 & 812 & 885 & 840 \\
spending & $(1178)$ & $(1277)$ & $(1705)$ & $(5288)$ & $(1454)$ & $(1701)$ & $(2969)$ \\
\hline N [Enrollees] & 172 & 2,032 & 7,551 & 14,131 & 19,706 & 13,217 & 56,809 \\
\hline
\end{tabular}

Standard deviations presented in parentheses.

Notes: family coverage is treated as one insurance unit. 
Table 4: Estimates of the Effect of Plan Characteristics on Health Care Spending

\begin{tabular}{|c|c|c|c|c|c|c|c|c|}
\hline & \multicolumn{2}{|c|}{ Total Spending } & \multicolumn{2}{|c|}{$\begin{array}{l}\text { Outpatient/Pharmacy } \\
\text { Spending }\end{array}$} & \multicolumn{2}{|c|}{ Out-of-pocket Spending } & \multicolumn{2}{|c|}{$\begin{array}{c}\text { Inpatient/Outpatient } \\
\text { Surgery Spending }\end{array}$} \\
\hline & OLS & IV & OLS & IV & OLS & IV & OLS & IV \\
\hline Spending account & $\begin{array}{l}1.23 \\
(0.17)^{* *}\end{array}$ & $\begin{array}{c}0.92 \\
(0.84)\end{array}$ & $\begin{array}{l}0.86 \\
(0.08) * *\end{array}$ & $\begin{array}{l}1.29 \\
(0.41)^{* *}\end{array}$ & $\begin{array}{c}0.04 \\
(0.05)\end{array}$ & $\begin{array}{l}-0.22 \\
(0.24)\end{array}$ & $\begin{array}{l}0.37 \\
(0.12)^{* *}\end{array}$ & $\begin{array}{l}-0.37 \\
(0.59)\end{array}$ \\
\hline Deductible & $\begin{array}{l}-0.55 \\
(0.13) * *\end{array}$ & $\begin{array}{l}-0.56 \\
(0.13) * *\end{array}$ & $\begin{array}{l}-0.26 \\
(0.06) * *\end{array}$ & $\begin{array}{l}-0.25 \\
(0.06) * *\end{array}$ & $\begin{array}{c}0.02 \\
(0.03)\end{array}$ & $\begin{array}{c}0.02 \\
(0.04)\end{array}$ & $\begin{array}{l}-0.29 \\
(0.08) * *\end{array}$ & $\begin{array}{l}-0.31 \\
(0.08) * *\end{array}$ \\
\hline In-network coinsurance & $\begin{array}{l}82.13 \\
(31.43)^{* *}\end{array}$ & $\begin{array}{l}82.69 \\
(31.64)^{* *}\end{array}$ & $\begin{array}{l}39.63 \\
(12.79)^{* *}\end{array}$ & $\begin{array}{l}38.83 \\
(12.58)^{* *}\end{array}$ & $\begin{array}{l}-1.03 \\
(4.73)\end{array}$ & $\begin{array}{l}-0.54 \\
(4.83)\end{array}$ & $\begin{array}{c}42.50 \\
(27.49)\end{array}$ & $\begin{array}{c}43.86 \\
(27.95)\end{array}$ \\
\hline Out-of-network coinsurance & $\begin{array}{c}-7.25 \\
(26.19)\end{array}$ & $\begin{array}{c}-6.66 \\
(26.60)\end{array}$ & $\begin{array}{c}11.63 \\
(12.64)\end{array}$ & $\begin{array}{c}10.79 \\
(12.72)\end{array}$ & $\begin{array}{l}-5.41 \\
(3.83)\end{array}$ & $\begin{array}{l}-4.90 \\
(3.93)\end{array}$ & $\begin{array}{l}-18.89 \\
(18.37)\end{array}$ & $\begin{array}{l}-17.45 \\
(18.59)\end{array}$ \\
\hline Hospital/surgery deductible & $\begin{array}{l}-0.29 \\
(0.13) *\end{array}$ & $\begin{array}{l}-0.30 \\
(0.13) *\end{array}$ & $\begin{array}{l}-0.22 \\
(0.10) *\end{array}$ & $\begin{array}{l}-0.21 \\
(0.10) *\end{array}$ & $\begin{array}{c}0.01 \\
(0.05)\end{array}$ & $\begin{array}{c}0.01 \\
(0.05)\end{array}$ & $\begin{array}{l}-0.08 \\
(0.05)\end{array}$ & $\begin{array}{l}-0.08 \\
(0.06)\end{array}$ \\
\hline OOP max & $\begin{array}{l}-0.01 \\
(0.05)\end{array}$ & $\begin{array}{l}-0.01 \\
(0.05)\end{array}$ & $\begin{array}{c}0.02 \\
(0.02)\end{array}$ & $\begin{array}{c}0.01 \\
(0.02)\end{array}$ & $\begin{array}{c}0.01 \\
(0.01)\end{array}$ & $\begin{array}{c}0.01 \\
(0.01)\end{array}$ & $\begin{array}{l}-0.02 \\
(0.04)\end{array}$ & $\begin{array}{l}-0.02 \\
(0.04)\end{array}$ \\
\hline Mean of Dep. Variable & \multicolumn{2}{|c|}{$\$ 4574$} & \multicolumn{2}{|c|}{$\$ 2731$} & \multicolumn{2}{|c|}{$\$ 840$} & \multicolumn{2}{|c|}{$\$ 1843$} \\
\hline
\end{tabular}

Notes: $n=56,809$ observations in 959 employers. Regressions control for age, gender, coverage type (employee, employee+1, employee+2 or more), number of dependents, calendar year, tenure (year) of enrollment and firm fixed effects. IV regressions use the following variables as instruments: company-year minimum of spending account balance, indicator for minimum account $=0$, and interactions between these two variables and deductible, in-network coinsurance, out-ofnetwork coinsurance, hospital/surgery deductible, and OOP maximum. The first-stage partial F statistic is 18.8 . Robust standard errors controlling for employerlevel clustering in parentheses: * significant at 5\%; ** significant at $1 \%$. 
Table 5: Estimates of the Effect of Plan Characteristics on Health Care Spending for Older and Younger Workers

\begin{tabular}{|c|c|c|c|c|c|c|c|c|}
\hline \multirow[b]{2}{*}{ Age group: } & \multicolumn{2}{|c|}{ Total Spending } & \multicolumn{2}{|c|}{$\begin{array}{l}\text { Outpatient/Pharmacy } \\
\text { Spending }\end{array}$} & \multicolumn{2}{|c|}{ Out-of-pocket Spending } & \multicolumn{2}{|c|}{$\begin{array}{l}\text { Inpatient/Outpatient } \\
\text { Surgery Spending }\end{array}$} \\
\hline & $>50$ & $<50$ & $>50$ & $<50$ & $>50$ & $<50$ & $>50$ & $<50$ \\
\hline Spending account & $\begin{array}{l}1.12 \\
(0.32)^{* *}\end{array}$ & $\begin{array}{l}1.40 \\
(0.18)^{* *}\end{array}$ & $\begin{array}{l}0.92 \\
(0.12)^{* *}\end{array}$ & $\begin{array}{l}0.90 \\
(0.09)^{* *}\end{array}$ & $\begin{array}{c}0.05 \\
(0.04)\end{array}$ & $\begin{array}{c}0.06 \\
(0.06)\end{array}$ & $\begin{array}{c}0.20 \\
(0.23)\end{array}$ & $\begin{array}{l}0.50 \\
(0.13)^{* *}\end{array}$ \\
\hline Deductible & $\begin{array}{l}-0.72 \\
(0.17) * *\end{array}$ & $\begin{array}{l}-0.42 \\
(0.21)^{*}\end{array}$ & $\begin{array}{l}-0.27 \\
(0.05) * *\end{array}$ & $\begin{array}{l}-0.26 \\
(0.11) *\end{array}$ & $\begin{array}{c}0.00 \\
(0.03)\end{array}$ & $\begin{array}{c}0.04 \\
(0.04)\end{array}$ & $\begin{array}{l}-0.45 \\
(0.14)^{* *}\end{array}$ & $\begin{array}{l}-0.17 \\
(0.12)\end{array}$ \\
\hline In-network coinsurance & $\begin{array}{c}62.48 \\
(99.73)\end{array}$ & $\begin{array}{l}90.23 \\
(24.88) * *\end{array}$ & $\begin{array}{l}61.60 \\
(27.29)^{*}\end{array}$ & $\begin{array}{l}31.07 \\
(12.24)^{*}\end{array}$ & $\begin{array}{l}-0.36 \\
(9.40)\end{array}$ & $\begin{array}{l}-1.35 \\
(4.34)\end{array}$ & $\begin{array}{c}0.88 \\
(86.73)\end{array}$ & $\begin{array}{l}59.16 \\
(19.45)^{* *}\end{array}$ \\
\hline Out-of-network coinsurance & $\begin{array}{l}-44.02 \\
(77.01)\end{array}$ & $\begin{array}{c}3.01 \\
(23.18)\end{array}$ & $\begin{array}{c}-4.32 \\
(28.38)\end{array}$ & $\begin{array}{c}14.08 \\
(12.33)\end{array}$ & $\begin{array}{l}-7.41 \\
(7.77)\end{array}$ & $\begin{array}{l}-4.32 \\
(3.47)\end{array}$ & $\begin{array}{l}-39.70 \\
(58.45)\end{array}$ & $\begin{array}{l}-11.06 \\
(15.26)\end{array}$ \\
\hline Hospital/surgery deductible & $\begin{array}{c}0.04 \\
(0.68)\end{array}$ & $\begin{array}{l}-0.32 \\
(0.11) * *\end{array}$ & $\begin{array}{c}0.00 \\
(0.22)\end{array}$ & $\begin{array}{l}-0.24 \\
(0.09)^{*}\end{array}$ & $\begin{array}{c}0.12 \\
(0.09)\end{array}$ & $\begin{array}{c}0.00 \\
(0.04)\end{array}$ & $\begin{array}{c}0.04 \\
(0.57)\end{array}$ & $\begin{array}{l}-0.08 \\
(0.04)^{*}\end{array}$ \\
\hline OOP max & $\begin{array}{l}-0.12 \\
(0.14)\end{array}$ & $\begin{array}{c}0.04 \\
(0.06)\end{array}$ & $\begin{array}{l}-0.06 \\
(0.05)\end{array}$ & $\begin{array}{c}0.04 \\
(0.02)\end{array}$ & $\begin{array}{c}0.01 \\
(0.02)\end{array}$ & $\begin{array}{c}0.01 \\
(0.01)\end{array}$ & $\begin{array}{l}-0.06 \\
(0.11)\end{array}$ & $\begin{array}{l}-0.00 \\
(0.04)\end{array}$ \\
\hline Observations & 14554 & 42255 & 14554 & 42255 & 14554 & 42255 & 14554 & 42255 \\
\hline Mean of Dep. Variable & $\$ 7,237$ & $\$ 3,657$ & $\$ 4,107$ & $\$ 2,257$ & $\$ 1,228$ & $\$ 706$ & $\$ 3,130$ & $\$ 1,400$ \\
\hline
\end{tabular}

Notes: OLS regressions are displayed. There are 959 employers for the $<50$ regressions and 853 employers for the $>50$ regression. Regressions control for age, gender, coverage type (employee, employee+1, employee+2 or more), number of dependents, calendar year, tenure (year) of enrollment and firm fixed effects.

Robust standard errors controlling for employer-level clustering in parentheses: * significant at 5\%; ** significant at $1 \%$. 
Figure 1: Static representation of budget constraint in the presence of a spending account (region 1), doughnut hole (region 2), deductible, and coinsurance after the deductible (region 3)

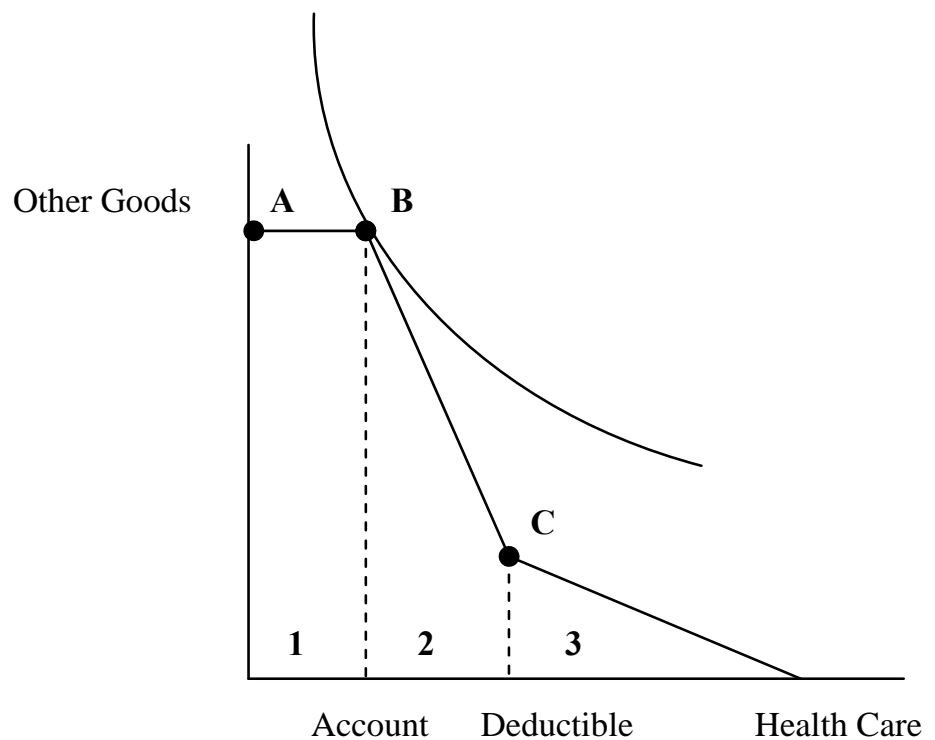

Panel A: Pre-change budget constraint

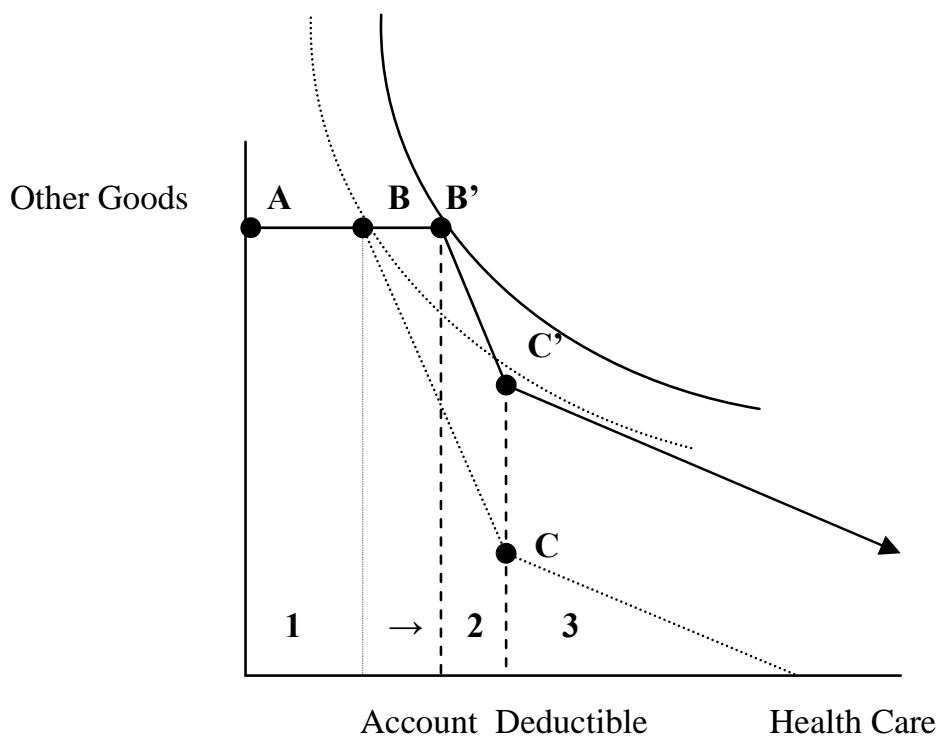

Panel B: Post spending account increase budget constraint 